\title{
Towards management of invasive ectomycorrhizal fungi
}

\author{
Ian A. Dickie $\mathbb{D} \cdot$ Martin A. Nuñez $\cdot$ Anne Pringle $\cdot$ Teresa Lebel • \\ Samuel G. Tourtellot $\cdot$ Peter R. Johnston
}

Received: 2 April 2016/Accepted: 27 July 2016/Published online: 4 August 2016

(C) The Author(s) 2016. This article is published with open access at Springerlink.com

\begin{abstract}
Ectomycorrhizal fungi are increasingly recognized as invasive species. Invasive ectomycorrhizal fungi can be toxic to humans, may compete with native, edible or otherwise valuable fungi, facilitate the co-invasion of trees, and cause major changes in soil ecosystems, but also have positive effects, enabling plantation forestry and, in some cases, becoming a valuable food source. Land-managers are interested in controlling and removing invasive fungi, but there are few available strategies for management and none are based on robust scientific evidence. Nonetheless, despite the absence of relevant experiments, we suggest that knowledge of the fundamental ecology of fungi can help guide strategies. We review the literature and suggest potential strategies for prevention, for slowing the spread of invasive fungi, for eradication, and for long-term management. In many cases the most appropriate strategy will be species and
\end{abstract}

I. A. Dickie $(\bowtie) \cdot S$. G. Tourtellot

Bio-Protection Research Centre, Lincoln University,

Room 436 Burns, P O Box 85084, Lincoln 7647,

New Zealand

e-mail: ian.dickie@lincoln.ac.nz

S. G. Tourtellot

e-mail: Samuel.Tourtellot@lincolnuni.ac.nz

\section{A. Nuñez}

Grupo de ecología de invasiones, INIBIOMA,

Universidad Nacional del Comahue/CONICET,

Bariloche, Argentina

e-mail: nunezm@gmail.com context (including country) specific. In order to effectively address the problems posed by invasive ectomycorrhizal fungi, land managers and scientists need to work together to develop and robustly test control and management strategies.

Keywords Biosecurity $\cdot$ Co-invasion - Invasive species $\cdot$ Mycology $\cdot$ Soil ecology $\cdot$ Symbioses

\section{Introduction}

Ectomycorrhizal fungi form symbiotic associations with plants, and are generally considered beneficial. Nonetheless, invasive ectomycorrhizal fungi can cause significant damage, ranging from human poisoning to ecosystem modification (Panel 1 in "Appendix"; Schwartz et al. 2006; Desprez-Loustau et al.

\footnotetext{
A. Pringle

Departments of Botany and Bacteriology, University of Wisconsin, Madison, WI, USA

e-mail: anne.pringle@wisc.edu

T. Lebel

National Herbarium of Victoria, Royal Botanic Gardens

Victoria, Melbourne, Australia

e-mail: Teresa.Lebel@rbg.vic.gov.au

P. R. Johnston

Landcare Research, Auckland, New Zealand

e-mail: JohnstonP@landcareresearch.co.nz
} 
2007; Vellinga et al. 2009). Despite scientific recognition of the spread and impact of invasive ectomycorrhizal fungi, there is little practical advice on management and few eradication strategies for invasive fungi. The lack of practical advice on invasive fungi stands in contrast with the abundant literature on control strategies for invasive plants and animals. Nonetheless we believe it is possible to formulate an expert opinion on possible removal strategies, based on aspects of basic fungal biology and comparison with other, better studied, invasive taxa (e.g., plants, animals). Further, we believe that proposing potential strategies is key to facilitating coordinated research and control efforts across international boundaries. With these goals in mind we (1) Provide a brief overview of the history and effects of ectomycorrhizal fungal invasions, (2) Discuss prevention, detection, and removal strategies for new incursions, recognizing proposed strategies are based on expert opinion and analogy to plant and animal invasions, and (3) Consider strategies to manage invasions and reduce the rate of spread, where removal is impossible.

\section{Historical invasions with long legacies}

The earliest introductions of ectomycorrhizal fungi were likely on the roots of plants moved through the nursery trade and between botanical gardens (e.g., Herriott 1919; Desprez-Loustau 2009; Vellinga and Kuyper 2012). Later, the recognition of the importance of ectomycorrhizal fungi to plantation forestry, particularly of pine (Pinus) species, led to more deliberate efforts at fungal introductions (Marx 1991; Rivera et al. 2015). Many countries now restrict the import of new species, but there is a continued international trade in mycorrhizal inocula and nursery stock associated with diverse, unknown fungi (International Plant Protection Convention 2013). Mycorrhizal inoculum of particular desirable species can also harbour non-target organisms, as suggested by Hall et al. (2008) for the spread of Tuber indicum and $T$. brumale with or on sporocarps of $T$. melanosporum, or as a contaminant on nursery inoculated seedlings. Sphagnum peat moss, widely used in commercial nursery production, can also be a vector of invasive fungi, with heat resistant strains remaining viable even after pasteurization (Ángeles-Argáiz et al. 2015). Once introduced, ectomycorrhizal fungi can naturalize through dispersal by mammals (Nuñez et al.
2013), wind, movement of soil, and by both inadvertent and deliberate spread by humans.

Most invasive ectomycorrhizal fungi remain restricted to alien plant hosts (Panel 2 in "Appendix"). While these fungi may not influence native plants directly, they have strong indirect effects by facilitating plant invasions of, for example, pines (Nuñez et al. 2009; Dickie et al. 2010; Hynson et al. 2013), Douglasfir (Pseudotsuga; Moeller et al. 2015), willows (Salix) and alders (Alnus; Bogar et al. 2015). Co-invasion with plants is probably the most geographically widespread effect of invasive ectomycorrhizal fungi and potentially the most damaging (Fig. 1). The phenomenon suggests tree species not currently widely invasive, such as Eucalyptus, may become more invasive if compatible fungi were to co-invade (Diez 2005; Vellinga and Kuyper 2012). A smaller number of invasive ectomycorrhizal fungi have spread onto native hosts (Orlovich and Cairney 2004; Pringle et al. 2009a, b), with largely unknown effects on plant physiology and native fungal communities (Dickie and Johnston 2008).

Invasive ectomycorrhizal fungi also affect ecosystem services, either directly or through co-invasion with plant hosts. Belowground, the invasion of ectomycorrhizal fungi and associated plants can cause a significant loss of soil carbon (up to $30 \%$ ), a movement of phosphorus into more labile pools, and at least a short-term transition to fast-nutrient cycling, bacterial-dominated decomposition (Chapela et al. 2001; Dickie et al. 2011). These soil changes can facilitate invasion by plant species adapted to high nutrient soils (Dickie et al. 2014b). Cultural and social ecosystem services are also directly impacted, as the invasion of fungi results in a global homogenisation and loss of sense-of-place. At the same time, invasive fungi may provide a number of beneficial ecosystem services, including enhanced timber production and production of edible mushrooms (Fig. 2).

The most dramatic effects of invasive ectomycorrhizal fungi on humans are caused by consumption of the toxic A. phalloides and the psychoactive $A$. muscaria (Nuñez and Dickie 2014). Amanita phalloides has established under planted alien trees in New Zealand and Australia, and invaded into native forests in North America (Pringle and Vellinga 2006; Pringle et al. 2009a, b; Wolfe et al. 2010). The species causes periodic poisonings. For example, four individuals died from eating A. phalloides in Canberra, Australia, a city of around 417,000, in 2013. While deadly 


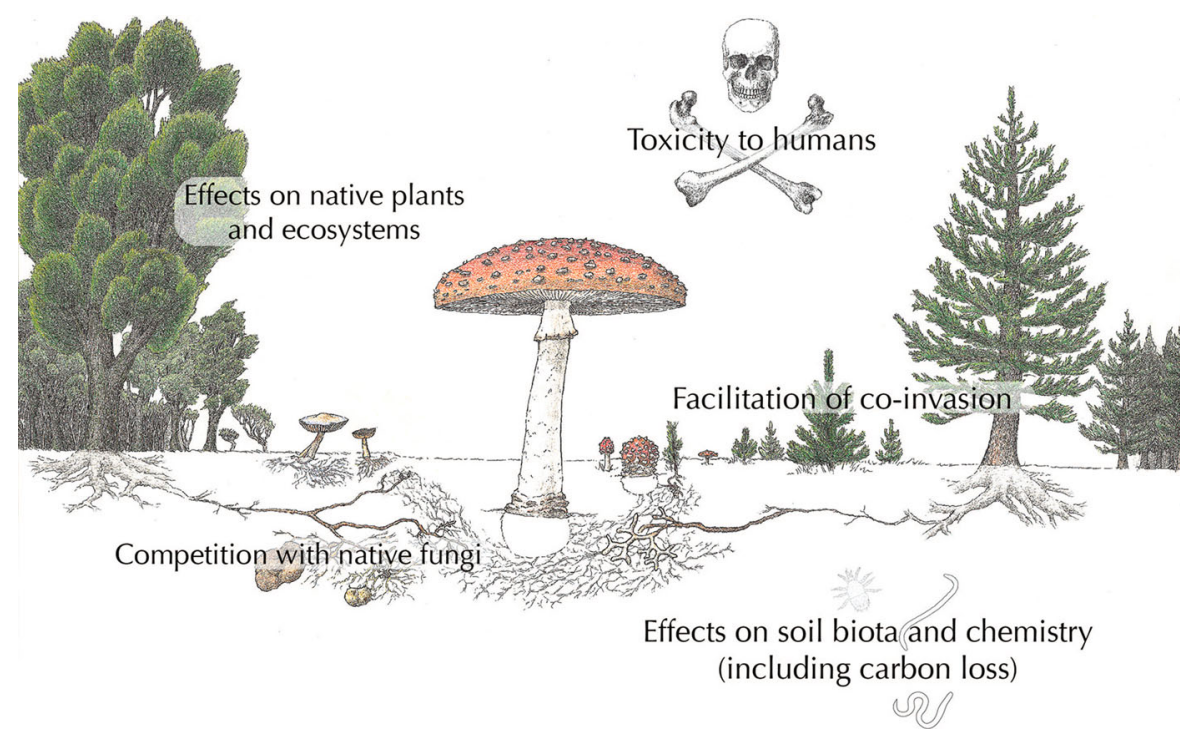

Fig. 1 Summary of key impacts of invasive ectomycorrhizal fungi. From top right clockwise: toxicity to humans, in particular, A. phalloides causes organ failure and death after consumption; facilitation of the co-invasion of alien trees, particularly invasive pines (Dickie et al. 2010); changes in soil, including release of recalcitrant nutrients, a loss of up to $30 \%$ of

poisonings are relatively rare, nonetheless $A$. phalloides is one of the few invasive macro-organisms that regularly causes human deaths. The high frequency of A. phalloides in urban parks and similar settings increases the risk of accidental poisonings (Page and Westcott 2014). Canberra now invests in removal of sporocarps from urban parks and both Canberra and Californian mycologists post warning signs (Fig. 3).

\section{Interest in management and eradication}

Whether or not to control or undertake removal of an invasive species is a decision based in policy, not science per se, as financial constraints, public perceptions, and feasibility are all considerations. Alien fungi valued for food or timber production provide ecosystem services that may drive conflict over invasive species removal (Fig. 2, see also Dickie et al. 2014b). Moreover, even understanding which species are invasive can be problematic, as determining any species' native or alien status can require extensive literature review (e.g., Pringle and Vellinga 2006) or detailed DNA analyses (e.g., Bogar et al. 2015). Nonetheless, there are clear examples where a desire to remove alien ectomycorrhizal fungi has been expressed by land managers. This includes interest in removal of soil C, loss of invertebrate diversity, and increased bacterial dominance (Chapela et al. 2001; Dickie et al. 2011, 2014a); competitive interactions with native and/or edible fungi (Murat et al. 2008); and likely, but as yet uncertain, effects on native plants and ecosystems. Image by Sam Tourtellot

Tuber indicum and T. brumale from the lands of commercial growers of higher value truffles (Hall et al. 2008), expressed concerns over Amanita muscaria invasion into native forests by regional councils in New Zealand (Dickie and Johnston 2008), and active efforts to remove A. phalloides sporocarps in Australia (Lebel personal communication). Widespread interest and effort to control the spread of, and removal of, invasive ectomycorrhizal plants (e.g., Pinus, Pseudotsuga, Salix, Alnus) is increasing. At present that effort has focused on the plants directly, but controlling the presence of the mutualisms supporting the plants is a potential alternative strategy. Thus both commercial and conservation groups have an expressed interest in control of invasive ectomycorrhizal fungi, most explicitly where those fungi are poisonous or threaten commercial harvests. In some cases, physical plant removal, chemical controls, and sporocarp removal have been proposed or undertaken (e.g., Hall et al. 2008), but until now there has been no review of the biological science underpinning those efforts (Fig. 3).

\section{Prevention is the best cure}

The best method of preventing fungal invasions is simply to never allow them to establish in the first place. Many countries now have barriers to the importation of 


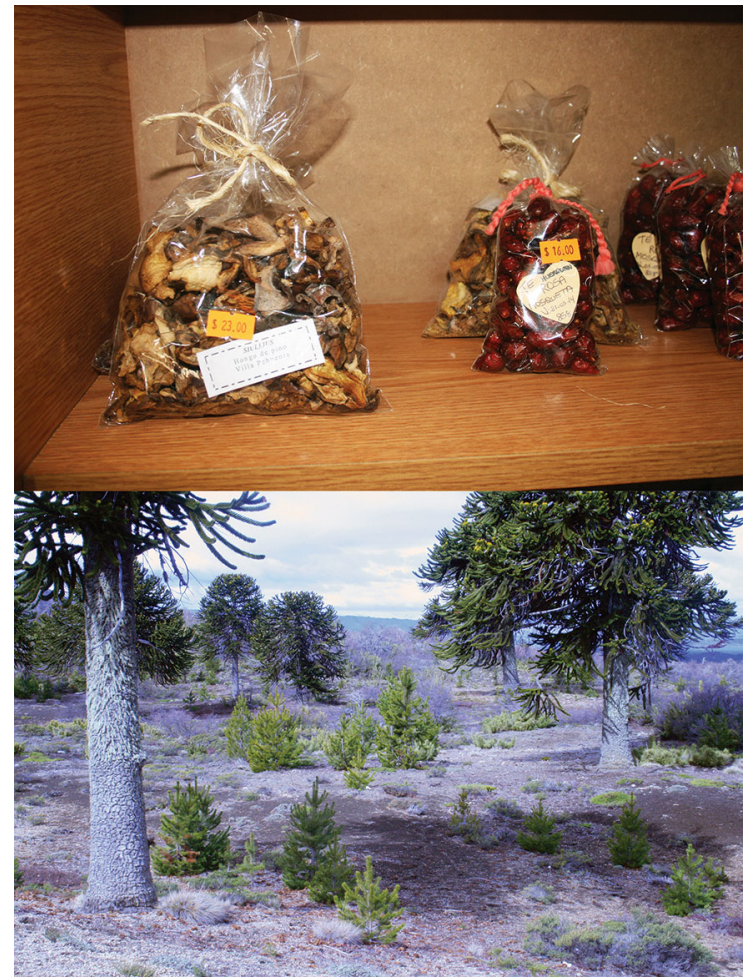

Fig. 2 The invasive fungus Suillus luteus sold as a high value food in an Argentinian grocery store (top), alongside rose hips from invasive Rosa spp., and the same fungus facilitating the invasion of invasive Pinus contorta into native Patagonian Araucaria forest (bottom). This species is an example of how invasive alien species can simultaneously provide both positive and negative ecosystem services (photos by IAD)

new species, including fungi, and the widespread introduction of species and movement of soil has slowed (International Plant Protection Convention 2013). Nonetheless, even within the scientific community there are persons who continue to undertake and promote the cross-continental translocation of fungi into natural ecosystems (Fardella et al. 2014). Advocacy to move species may be a particular issue for mycorrhizal and endophytic fungi, which can be seen as "beneficial" and therefore not-of-concern. However, clear evidence of negative impacts confirms that the global spread of symbiotic fungi comes with significant risk (Schwartz et al. 2006; Nuñez et al. 2015).

While prevention is an obvious control strategy, its efficacy is limited by economic pressures to allow the movement of plants and fungi. For example, plantation forestry and truffières in many countries rely on alien trees and their associated alien ectomycorrhizal fungi (e.g., Walbert et al. 2010; Hynson et al. 2013).
Even in countries with a high level of biosecurity awareness, nursery stock is typically screened for disease symptoms and culturable fungi, but not for the generally difficult to culture ectomycorrhizal fungi on plant roots. Further, plants are frequently moved by individuals for gardens or small-scale plantings, with little consideration of what fungi may also be moved.

Further complicating prevention, many future ectomycorrhizal invaders are likely already present, as mycorrhizas on roots of amenity plantings and forest plantations, or potentially as spores in the soil. In plant and animal invasions, many species show extended periods between introduction and detection of naturalization and spread, either due to the initially slow phases of exponential growth from small populations or true lag-phases in invasion (Aikio et al. 2010). Alien trees often occur around farmsteads, arboreta, research stations, and campgrounds within high conservation-value landscapes, and many are likely to support populations of alien fungi.

A strategy for prevention: the use of alternative inocula and eco-sourced soil

Ectomycorrhizal plants rely on fungi for normal establishment and growth, and the elimination of all mycorrhizas from nursery grown seedlings is not a viable strategy for preventing invasions. A more effective strategy may involve the deliberate choice of inocula from either less-invasive alien fungi or native fungi (Azul et al. 2014; Hayward et al. 2015). Nursery inoculation is a fairly well understood process, and uses mycelial cultures, fungal spores, or soil from established stands (and even fungivorous mammal fecal pellets). The early inoculation of seedlings with target native species may prevent the establishment of potentially invasive species, as fungal communities often show strong priority effects (Kennedy and Bruns 2005). Moreover, "eco-sourcing", defined as the use of native soil from nearby locations, may allow the establishment of a more intact native soil community on plants, one involving more than just ectomycorrhizal fungi.

Alternative inocula and eco-sourced soils are relatively cheap tools likely to reduce the spread of alien mycorrhizal fungi. Using soil from an intact forest as inoculum requires consideration of the impacts of soil collection, and may be most suited to small scale production. In addition, the potential for introduction of pathogens is a risk with this strategy. At the least, we 


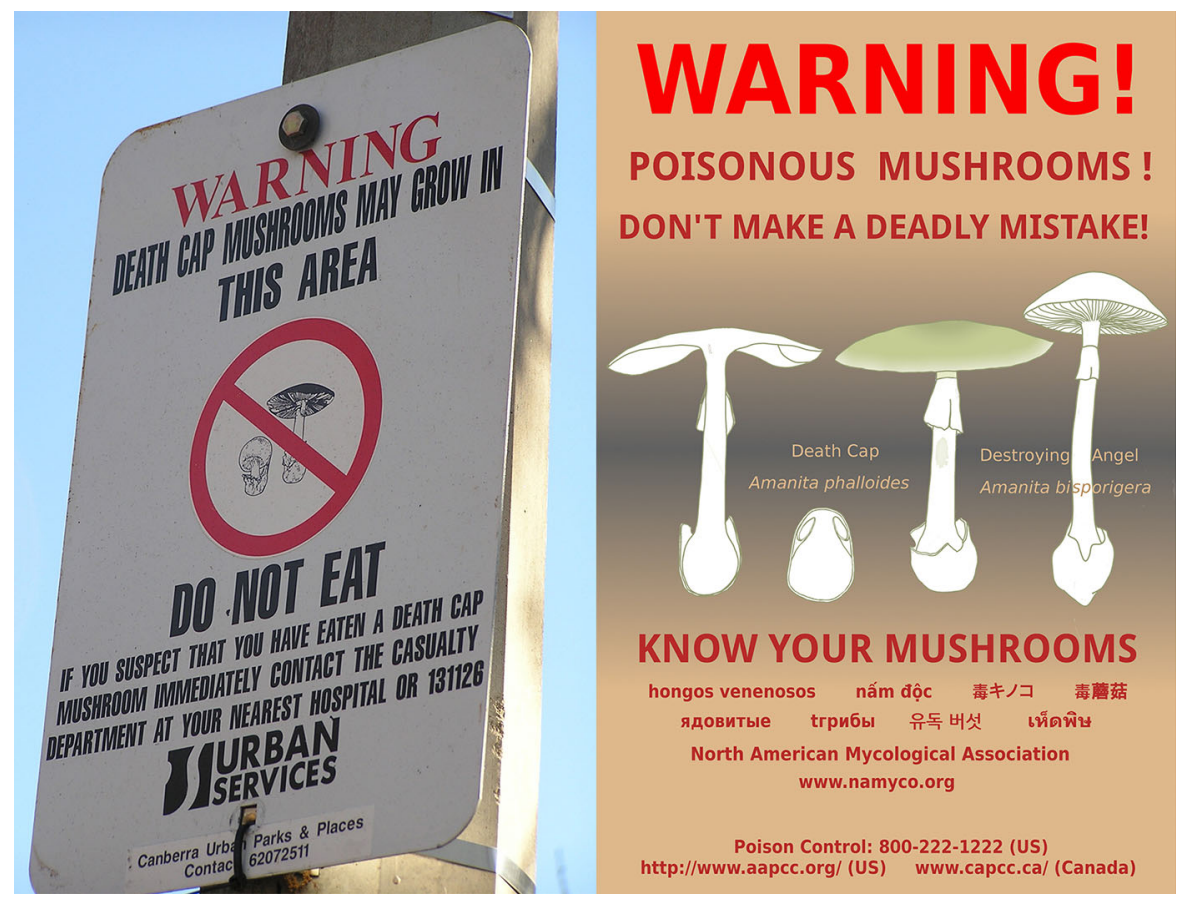

Fig. 3 Toxic Amanita phalloides represents one of the relatively few invasive species able to kill people. The warning sign from Canberra, Australia (left) is in English only; whether the sign will reach some of the most at-risk groups (including Asian immigrants) is unclear. The North American Mycological Association warning poster (right) addresses the language barrier. We note a clinical trial is underway in the U.S.A. to test the efficacy of

endorse careful consideration of what fungi are present on plant roots in any planting, whether alien or native. But the use of less-invasive and native fungi in ectomycorrhizal inoculation may represent low-impact prevention strategies, and should be a part of ongoing efforts to research the management of ectomycorrhizal invasions.

\section{Early detection is key to eradication}

A fundamental principle of invasive plant management is the value of early detection and rapid response (Rejmánek and Pitcairn 2002). In many countries existing amateur mycological societies represent highly-engaged citizen science opportunities and these groups can be effectively enlisted in the early detection of invasions (Dickinson et al. 2012). The increasing global use of smart-phones provides remarkable abilities to photo-document, GPS, and record fungal specimens in unprecedented detail (e.g., naturewatch.org.nz, mushroomobserver.org, fungimap.org.au). intravenous milk thistle as a therapy (www.clinicaltrials.gov/ct2/ show/study/NCT00915681). Although milk thistle is already available and used as a therapy in Europe, where A. phalloides is native, and Australia, where it is invasive, it was not available in the U.S.A. until very recently. Canberra photo public domain from http://commons.wikimedia.org/wiki/File:Death_Cap_Mushroom. jpg, image from NAMA used with permission

Early detection may be biased towards the discovery of highly visible invasive fungi (e.g., the bright orange/red A. muscaria, and saprotrophs Favolaschia calocera and Clathrus archeri). Indeed, for many of the more cryptic fungi (e.g., fungal crusts, including species of Tomentella, and species that sporulate in soil) it may not be clear what is native. This may limit the utility of citizen science somewhat. We suggest amateur mycologists should be increasingly incorporated into invasive species detection and post-control monitoring, but that this would be most effective as part of a broader effort, combined with outreach and education, including education about cryptic species.

\section{Slowing the spread}

Removal of human vectors

Invasive ectomycorrhizal fungi are frequently associated with trails, camping sites, and other areas where they are 
likely to come into contact with boots, shoes, vehicles, and camping gear. We have also observed individual hikers deliberately picking and transporting sporocarps tens to hundreds of meters along trails and, in the case of edible fungi, deliberately attempting to spread the population (T. Lebel and I. Dickie, personal observations). Machinery and bulk soil movement during track and road maintenance are also major vectors that need be addressed through policy and engagement.

Washing of vehicles and boots has been used to try to reduce the spread of Phytophthora (Goheen et al. 2012), although whether it is actually effective remains largely unknown. There is anecdotal evidence of hikers walking past rather than using cleaning stations despite signage. Closing of infected forests to the public is also being used as a strategy to block Phytophthora in Australia and New Zealand. It is possible to adopt these strategies for invasive ectomycorrhizal fungi. Because ectomycorrhizal fungi may spread from alien plantations, another option is to reroute trails to avoid having walkers or mountain-bikers pass from alien plantations directly into native forests.

On the whole, public engagement with fungal invasions, including strategies to reduce spread, is likely to have positive outcomes, even if it has limited effectiveness as an actual control strategy. Lessons from invasive tree management suggest that conflict over invasive species removal is highly likely; early communication and engagement may help alleviate potential problems.

\section{Removal or blocking of mammal vectors}

In both Argentina and New Zealand alien mammals play an important role in dispersing invasive ectomycorrhizal fungi (Nuñez et al. 2013). Animal dispersal may include transmission either on feet and fur of animals, or transmission through the gut (Ashkannejhad and Horton 2006; Wood et al. 2015). Some mammal movement can be blocked through fencing at edges of plantations, or at other invasion sites. In other cases, the spread of invasive fungi may be a contributing factor in deciding to remove alien mammals, however this is not an option where mammals are native or desirable aliens. Fencing and hunting are expensive, but may sometimes be effective strategies, for example where alien forest plantations are established at the edge of conservation areas. It may also be possible to use buffer zones between plantations and conservation areas to minimize animal movement between habitats.

\section{Eradication methods depend on context}

Manual removal of sporocarps

The intensive harvesting of native, edible fungi is a conservation concern, because collecting a species' reproductive structures may cause declines in populations, analogous to picking all wildflowers from a meadow, year after year (Pilz and Molina 2002). But if the aim is to eliminate an invasive fungus, perhaps repeatedly harvesting sporocarps is a good strategy? Short lived, highly sexual species with ephemeral spores are the best target for control by sporocarp removal. $A$. phalloides appears to be this kind of fungus, at least in California; individuals are typically $<1 \mathrm{~m}$ in size, appear to establish from spores, and are short lived (Pringle, unpublished data). If every mushroom were picked before new spores were released, there is a chance the species would be eliminated, at least from a local habitat, moreover, the total number of spores dispersing to new habitats would be reduced.

Currently available evidence suggests picking mushrooms has little impact on populations (Egli et al. 2006; Luoma et al. 2006), at least over larger areas, but published experiments do not target fungi with life histories typical of $A$. phalloides. Manual removal is easily implemented, low cost, and offers the potential for outreach and citizen science. Manual removal may be a high priority in specific contexts, for example, poisonous mushrooms around daycare centers or preschools. In Australia, multiple deaths in the last few years contributed to a decision by the Royal Botanic Gardens Victoria to manually remove and record numbers of $A$. phalloides sporocarps (Lebel personal communication). Picking edible mushrooms for consumption may slow the spread of some fungi, but invites conflict over invasive species removal by potentially creating or contributing to their economic and cultural value (Nuñez et al. 2012).

\section{Application of fungicide}

Fungicide is a simple, intuitive response to a fungal invasion, analogous to the widespread use of herbicides, insecticides, and other poisons in other invasive species management. Fungicides are also unlikely to cause obvious damage and antagonize public opinion, although there is often resistance to the spraying of biocides in general. Fungicides reduce ectomycorrhizal infections on seedlings when used as root 
drenches, or in greenhouse pots (Teste et al. 2006). However, fungicides may not eliminate fungi, are inconsistent in their effects across taxa, and appear to reduce ectomycorrhizal infections only when applied well above normal recommended rates (Trappe et al. 1984). Further, no fungicide targets ectomycorrhizal fungi exclusively, and any potential reduction in the population of the invasive ectomycorrhizal fungus will have to be considered against non-target effects and damage to native fungi.

Given current evidence, we suggest fungicides are relatively low cost, but have a very low probability of success and moderately high non-target effects. Fungicides may be most useful in preventing fungal spread with nursery stock, but we do not recommend fungicide for removal of established populations.

\section{Trenching}

To survive, an ectomycorrhizal fungus must be in symbiosis with a plant. In principle, it may be possible to sever hyphal connections to a host by deeply trenching, cutting all hyphae and roots around the perimeter of an invasive fungal population and inserting a barrier to prevent root or hyphal regrowth. Trenching has been proposed as a mechanism for slowing the spread of fungi and pine trees as coinvaders (Thiet and Boerner 2007). Where invasions are small scale and any seedlings or trees included within the trenched area can be killed, trenching should effectively cut off the carbon supply to the fungus and result in fungal death, although manual removal of sporocarps might be necessary in the first year, to prevent dispersal.

Although attractive in theory, trenching remains untested as a method to kill fungi. Data from posttimber harvesting suggests that ectomycorrhizal fungi may persist in a living vegetative state for several years after removal of plant hosts (Jones et al. 2003). Some fungi may also survive as persistent spores or sclerotia (Glassman et al. 2015) or in a saprotrophic state. Monitoring and periodic seedling removal might be required to prevent premature re-establishment of plant hosts. One of the major unknown variables is the spatial extent of hyphae beyond the immediate area of sporocarps. Even for small, early detection events it might be necessary to trench at some distance beyond the perimeter of observed sporocarps.
Trenching is labour intensive and hence expensive. It has a high probability of reducing the rate of mycelial spread, but does not reduce spore based spread and will only eradicate populations when combined with elimination of hosts. Non-target effects are generally minimal. We recommend trenching as part of a removal strategy for localized, small-scale invasions, and as part of a containment strategy at the edge of invasions or plantations. Trenching may also be appropriate where trees supporting harmful fungi occur outside but adjacent to high-risk areas (e.g., playgrounds in the context of A. phalloides).

\section{Elimination of hosts}

Following the same logic as trenching, the carbon supply to an invasive ectomycorrhizal fungus can be eliminated by killing all host plants supporting the invasive fungal population. The deliberate killing of trees has been used to slow the spread of pathogens (Goheen et al. 2012), either to remove infected trees or to remove susceptible individuals along roadsides.

In the invasion of $A$. muscaria into native forests in $\mathrm{NZ}$, invasive populations tend to be small and spread slowly. There are a few cases where populations have established at long distances from any other invasive populations. At least in principle, it would be logical to sacrifice a few trees in a large area of otherwise uninvaded forest in order to halt an isolated fungal invasion.

Eliminating all trees supporting an invasive ectomycorrhizal fungus is likely to eliminate the fungus, provided that all links to living plants are severed and spore banks are not persistent. In the case of early detection, this technique might be effectively combined with trenching. However, killing healthy trees is likely to provoke a strong negative reaction from the public, which may prevent widespread adoption. Public outrage is likely to be more of an issue than it is with invasive pathogens, where tree mortality is simply accelerated.

\section{Management of widespread invasions}

\section{Biocontrol}

Once invasive species of almost any type are widespread, eradication becomes almost inconceivable, and biological control becomes one of the few remaining options. In 
general, biological control is not aimed at removal of species, but rather a reduction in abundance. Fungi are widely used as agents of biocontrol of, for example, invasive plants (Ellison et al. 2008) and arthropod pests (Hajek and Delalibera 2010), but are also potential targets of biocontrol. Most biocontrol of fungi focuses on protecting seeds or individual plants from pathogens (Bressan 2003), or preventing decay (Melent'ev et al. 2006). In the field, a hypovirus has been used for biocontrol of chestnut blight, with some success (Milgroom and Cortesi 2004).
Ectomycorrhizal fungi are known to be susceptible to pathogenic fungi, particularly Hypomyces, some species of which have a fairly high level of specificity to particular fungal genera or sub-genera (Douhan and Rizzo 2003). We can find no examples where biological control has been used with the goal of controlling invasive ectomycorrhizal fungi, but it is an area that should be explored. One particular concern may be around risk to native species, as in many cases invasive ectomycorrhizal fungi are in the same genera as native fungal species.
Fig. 4 Schematic of proposed management strategies for prevention, control and slowing of ectomycorrhizal fungal invasions. Biological control illustrated as a Hypomyces infected sporocarp. Illustration by ST

\section{Prevention}
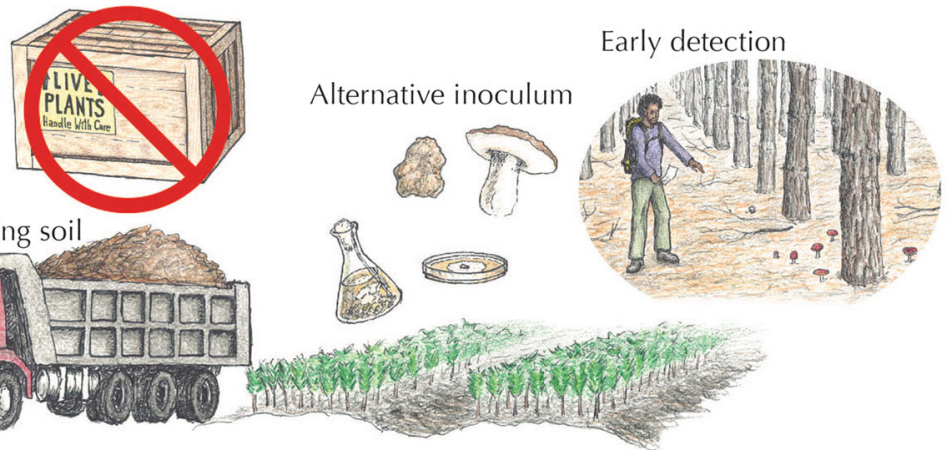

Control and eradication

Slowing the spread, reducing population

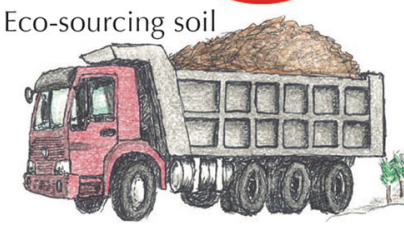

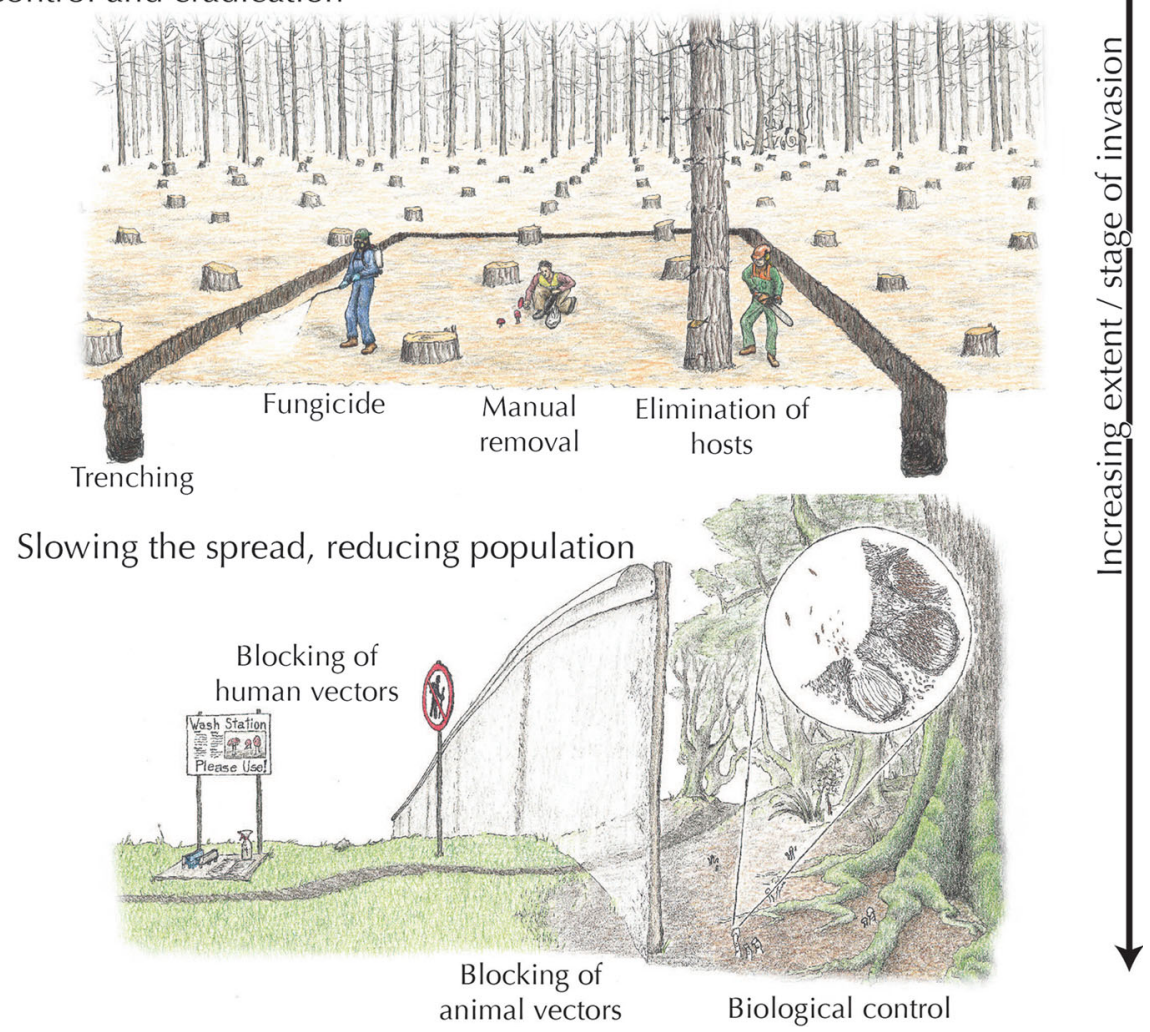


Long-term management

Where alien fungi are already widespread, or where economic or other benefits of fungi make eradication impossible or untenable, there may still be options for reducing associated undesirable impacts. Many invasive species thrive in disturbed habitats (MacDougall and Turkington 2005), which is likely to be true of invasive ectomycorrhizal fungi as well. For example, the invasion of A. muscaria into native forests is frequently associated with roads and tracks, which may be related to disturbance as well as vectors of introduction (Dunk et al. 2012). Co-invasion of pines and fungi is frequently into grasslands induced by agricultural clearing (e.g., Dickie et al. 2010), but cases of invasion into undisturbed forest are also known (Wolfe et al. 2010; Moeller et al. 2015). Nonetheless, ecosystem management to avoid soil disturbance, and protect or restore native ecosystems may contribute to maintaining native fungal populations and reducing co-invasion, despite being unlikely to eliminate invasive ectomycorrhizal fungi altogether.

\section{Conclusions: a call for land managers and scientists to join efforts}

At present the control of invasive ectomycorrhizal fungi seems stuck at an impasse. Land managers are interested in trying to remove invasive fungi, but are unable to find evidence-based guidance on how to do so. At the same time, it is difficult to obtain funding to research potential methods in the absence of any active attempts to eliminate invasions. We suggest that the only way to move forward is to combine management and research efforts. Land managers who are contemplating or undertaking control efforts should seek out scientific advice on possible strategies (Fig. 4) and on robust experimental design of trials. In particular, partnerships should be designed where land managers benefit from scientific expertise while contributing to furthering scientific knowledge. Conversely, scientists need to recognise that land managers have their own constraints, including limited budgets, and a need for timely, clearly presented results. Further, land managers often have a justifiable unwillingness to leave invasive species in plots as experimental controls. Rapid publication in international sources is particularly critical to benefit from robust peer review and to build knowledge across regions and countries.
What are the consequences of not doing anything? In the absence of a concerted effort to eliminate invasives, invasions by ectomycorrhizal fungi will inevitably continue, likely driven both by alien fungi already present on planted trees and new introductions. These invasions are likely to facilitate additional invasions by alien ectomycorrhizal trees, result in major changes to soil nutrient and carbon cycling, and directly impact human health. Other impacts, particularly on native plant health and on native fungal biodiversity, are less certain, but the absence of any evidence of harm should not be taken as evidence against such harm. Indeed, the precautionary principle would favour removing and limiting the spread of fungi until and unless future research supports a benign outcome.

We note that there are significant ancillary benefits likely to emerge from research on and management of invasive ectomycorrhizal fungi. Many invasive trees are co-invading with fungi, and managing the spread of the fungi may be an additional strategy towards managing these trees. Further, the large, conspicuous sporocarps of many invasive mycorrhizal fungi make them easier to study than invasive pathogens, and hence a model system for understanding fungal invasions. Finally, because many species are charismatic they are ideal systems for engaging the public in conservation and biosecurity.

Acknowledgments Discussions with C. Nuñez, from the Administración de Parques Nacionales, Argentina, J. Bufford, J. Cooper, P. Hulme, and the BioProtection weed group contributed to this review. We thank Jerry Cooper, Michael Wood, Antonio Rodríguez, and the American Mycological Association for permission to use images. IAD and ST supported by Bio-Protection Research Centre funding from the NZ Tertiary Education Commission, and MN (DEB 948930) and AP supported by the U.S. National Science Foundation.

Open Access This article is distributed under the terms of the Creative Commons Attribution 4.0 International License (http:// creativecommons.org/licenses/by/4.0/), which permits unrestricted use, distribution, and reproduction in any medium, provided you give appropriate credit to the original author(s) and the source, provide a link to the Creative Commons license, and indicate if changes were made.

\section{Appendix}

Panel 1: Examples of genera and species of invasive ectomycorrhizal fungi, where they are found, and effects on ecosystem services (impacts and benefits) 


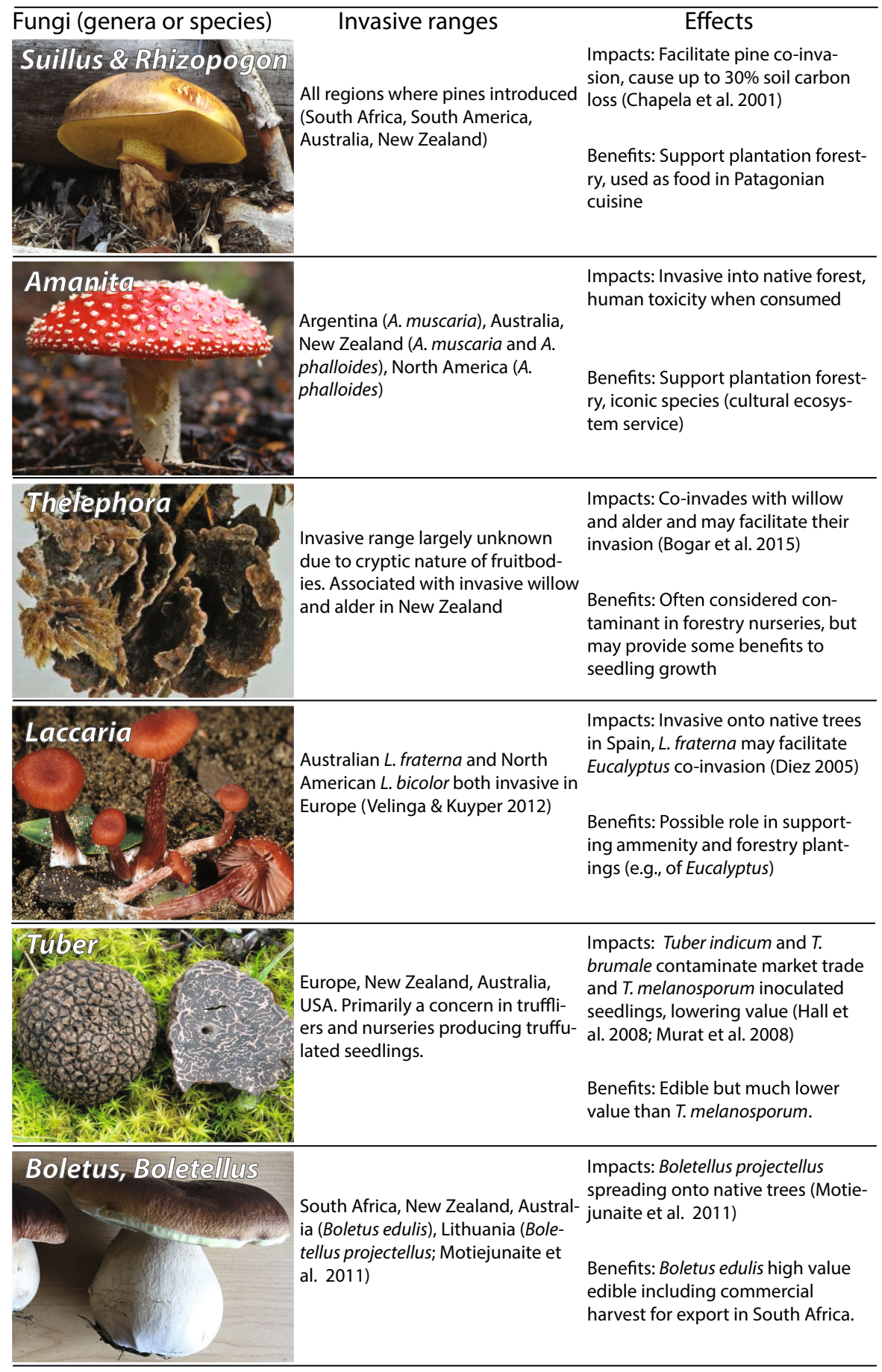

Images of Tuber indicum by A. Rodríguez, Laccaria fraterna by M. Wood, and Thelephora terrestris by J. Cooper used with permission. Other images by IAD. 
Panel 2: When is an ectomycorrhizal fungus

"invasive"?

The word "invasive" has generated significant controversy, with debate focused on whether the term is defined by negative impacts or by biogeographic spread. Here we adopt the unified framework for biological invasions of Blackburn et al. (2011), which is entirely based on spread and not impact. We use three terms from that framework, "alien" for all species not native to a location, "naturalised" for alien species with self-sustaining populations outside of cultivation, and "invasive" for species with selfsustaining populations at significant distances from the original introduction.

Invasive ectomycorrhizal fungi present an additional controversy, because whether or not an ecto- mycorrhizal fungus is defined as "invasive" may depend on whether or not it associates with native plants. Here we follow Nuñez and Dickie (2014), and define a fungus as invasive whenever it is found distant from the original site of introduction, regardless of symbiotic associations. Our definition does not require a shift to associations with native plants (compare with Pringle et al. 2009a, b). Defining an invasive fungus according to host associations creates an illogical asymmetry, with the fungus only considered invasive when symbiotic with a novel plant, while the plant is considered invasive regardless of fungal associations. Nonetheless, invasive ectomycorrhizal fungi can be meaningfully divided into those that co-invade with their original alien plant associates, and those that form novel associations with native trees (Nuñez and Dickie 2014) (Table 1).

Table 1 The stages of ectomycorrhizal invasion based on Blackburn et al. (2011) with examples of some of the major actors and drivers of each stage

\begin{tabular}{|c|c|c|}
\hline Stage & Actors/drivers & Selected examples \\
\hline \multirow[t]{2}{*}{ 1. Transport } & Nursery trade & $\begin{array}{l}\text { Global trade in live plants, sphagnum, and fungal } \\
\text { inoculum }\end{array}$ \\
\hline & $\begin{array}{l}\text { Imported inoculum } \\
\text { Researchers }\end{array}$ & Establishment of new edible fungi \\
\hline 2. Introduction & $\begin{array}{l}\text { Forest plantations } \\
\text { Urban plantings }\end{array}$ & Mycorrhizal fungi on roots of out-planted seedlings \\
\hline 3. Establishment & $\begin{array}{l}\text { Host plant availability } \\
\text { Habitat suitability }\end{array}$ & $\begin{array}{l}\text { Diverse alien fungi in forestry plantations and urban } \\
\text { settings }\end{array}$ \\
\hline \multicolumn{3}{|l|}{ 4. Spread } \\
\hline 4a. Co-invasion, slower than host & Wind and mammal dispersal & $\begin{array}{l}\text { Boletus edulis on oaks and Pinaceae in New } \\
\text { Zealand, Tuber indicum on oaks in New Zealand } \\
\text { and Australia }\end{array}$ \\
\hline 4b. Co-invasion with alien plants & & $\begin{array}{l}\text { Suillus, Rhizopogon with invasive Pinaceae } \\
\text { worldwide }\end{array}$ \\
\hline $\begin{array}{l}\text { 4c. Novel associations with native } \\
\text { plants in disturbed habitats }\end{array}$ & Human transport & A. muscaria in urban plantings and near roads \\
\hline $\begin{array}{l}\text { 4d. Novel associations with native } \\
\text { plants in intact habitats }\end{array}$ & & $\begin{array}{l}\text { A. muscaria in generally intact Nothofagaceae } \\
\text { forests in southern hemisphere, A.phalloides in } \\
\text { CA, USA on native oaks, T. indicum in Eastern } \\
\text { USA on loblolly pine and pecan }\end{array}$ \\
\hline
\end{tabular}




\section{References}

Aikio S, Duncan RP, Hulme PE (2010) Lag-phases in alien plant invasions: separating the facts from the artefacts. Oikos 119:370-378

Ángeles-Argáiz RE, Flores-García A, Ulloa M, Garibay-Orijel $\mathrm{R}$ (2015) Commercial sphagnum peat moss is a vector for exotic ectomycorrhizal mushrooms. Biol Invasions 18:89-101. doi:10.1007/s10530-015-0992-2

Ashkannejhad S, Horton TR (2006) Ectomycorrhizal ecology under primary succession on coastal sand dunes: interactions involving Pinus contorta, suilloid fungi and deer. New Phytol 169:345-354

Azul AM, Nunes J, Ferreira I, Coelho AS, Veríssimo P, Trovão J, Campos A, Castro P, Freitas H (2014) Valuing native ectomycorrhizal fungi as a mediterranean forestry component for sustainable and innovative solutions 1. Botany 92:161-171

Blackburn TM, Pyšek P, Bacher S, Carlton JT, Duncan RP, Jarošík V, Wilson JR, Richardson DM (2011) A proposed unified framework for biological invasions. Trends Ecol Evol 26:333-339

Bogar LM, Dickie IA, Kennedy PG (2015) Testing the co-invasion hypothesis: ectomycorrhizal fungal communities on Alnus glutinosa and Salix fragilis in New Zealand. Divers Distrib 21:268-278

Bressan W (2003) Biological control of maize seed pathogenic fungi by use of actinomycetes. Biocontrol 48:233-240

Chapela IH, Osher LJ, Horton TR, Henn MR (2001) Ectomycorrhizal fungi introduced with exotic pine plantations induce soil carbon depletion. Soil Biol Biochem 33:1733-1740

Desprez-Loustau ML (2009) Alien fungi of Europe. In: Daisie (ed) Handbook of alien species in Europe. Springer, Netherlands, pp 15-28

Desprez-Loustau ML, Robin C, Buee M, Courtecuisse R, Garbaye J, Suffert F, Sache I, Rizzo DM (2007) The fungal dimension of biological invasions. Trends Ecol Evol 22:472-480

Dickie IA, Johnston PR (2008) Invasive fungi research priorities, with a focus on Amanita muscaria. Landcare Research, Lincoln

Dickie IA, Bolstridge N, Cooper JA, Peltzer DA (2010) Coinvasion by Pinus and its mycorrhizal fungi. New Phytol 187:475-484

Dickie IA, Yeates GW, St John MG, Stevenson BA, Scott JT, Rillig MC, Peltzer DA, Orwin KH, Kirschbaum MU, Hunt JE, Burrows LE (2011) Ecosystem service and biodiversity trade-offs in two woody successions. J Appl Ecol 48:926-934

Dickie IA, Stjohn MG, Yeates GW, Morse CW, Bonner KI, Orwin K, Peltzer DA (2014a) Belowground legacies of Pinus contorta invasion and removal result in multiple mechanisms of invasional meltdown. AoB Plants. doi:10. 1093/aobpla/plu056

Dickie IA, Bennett BM, Burrows LE, Nunez MA, Peltzer DA, Porté A, Richardson DM, Rejmánek M, Rundel PW, van Wilgen BW (2014b) Conflicting values: ecosystem services and invasive tree management. Biol Invasions 16:705-719
Dickinson JL, Shirk J, Bonter D, Bonney R, Crain RL, Martin J, Phillips T, Purcell K (2012) The current state of citizen science as a tool for ecological research and public engagement. Front Ecol Environ 10:291-297

Diez J (2005) Invasion biology of Australian ectomycorrhizal fungi introduced with eucalypt plantations into the Iberian Peninsula. Biol Invasions 7:3-15

Douhan GW, Rizzo DM (2003) Host-parasite relationships among bolete infecting Hypomyces species. Mycol Res 107:1342-1349

Dunk CW, Lebel T, Keane PJ (2012) Characterisation of ectomycorrhizal formation by the exotic fungus Amanita muscaria with Nothofagus cunninghamii in Victoria, Australia. Mycorrhiza 22:135-147

Egli S, Peter M, Buser C, Stahel W, Ayer F (2006) Mushroom picking does not impair future harvests: results of a longterm study in Switzerland. Biol Conserv 129:271-276

Ellison CA, Evans HC, Djeddour DH, Thomas SE (2008) Biology and host range of the rust fungus Puccinia spegazzinii: a new classical biological control agent for the invasive, alien weed Mikania micrantha in Asia. Biol Control 45:133-145

Fardella C, Oses R, Torress-Diaz C, Molina-Montenegra MA (2014) Hongos endófitos antárticos como herramienta para la reintroducción de especies nativas en zonas áridas. Bosque 35:235-239

Glassman SI, Peay KG, Talbot JM, Smith DP, Chung JA, Taylor JW, Vilgalys R, Bruns TD (2015) A continental view of pine-associated ectomycorrhizal fungal spore banks: a quiescent functional guild with a strong biogeographic pattern. New Phytol 205:1619-1631

Goheen DJ, Mallams K, Betlejewsk IF, Hansen E (2012) Effectiveness of vehicle washing and roadside sanitation in decreasing spread potential of port-orford-cedar root disease. West J Appl For Sci 27:170-175

Hajek AE, Delalibera I (2010) Fungal pathogens as classical biological control agents against arthropods. Biocontrol 55:147-158

Hall I, Zambonelli A, Nelson P (2008) Distinguishing the Périgord black truffle from the winter truffle and other look-alikes in the laboratory and field. Truffles \& Mushrooms (Consulting) Ltd. http://www.trufflesandmushrooms. co.nz/Distinguishing $\% 20$ the $\% 20$ Perigord $\% 20$ black $\% 20$ truffle\%20from\%20look-alikes.pdf Accessed 3 April 2016

Hayward J, Horton TR, Nuñez MA (2015) Ectomycorrhizal fungal communities co invading with Pinaceae host plants in Argentina: gringos bajo el bosque. New Phytol 208:497-506

Herriott EM (1919) A history of Hagley Park, Christchurch, with special reference to its botany. Trans Proc R Soc NZ 51:427-447

Hynson NA, Merckx VSFT, Perry BA, Treseder KK (2013) Identities and distributions of the co-invading ectomycorrhizal fungal symbionts of exotic pines in the Hawaiian Islands. Biol Invasions 15:2373-2385

International Plant Protection Convention (2013) 2005-004: Movement of growing media in association with plants for planting in international trade, Draft ISPM. Food and Agriculture Organization of the United Nations. https:// www.ippc.int/en/publications/2257/. Last Accessed 2 Aug 2016 
Jones MD, Durall DM, Cairney JWG (2003) Ectomycorrhizal fungal communities in young forest stands regenerating after clearcut logging. New Phytol 157:399-422

Kennedy PG, Bruns TD (2005) Priority effects determine the outcome of ectomycorrhizal competition between two Rhizopogon species colonizing Pinus muricata seedlings. New Phytol 166:631-638

Luoma DL, Eberhart JL, Abbott R, Moore A, Amaranthus MP, Pilz D (2006) Effects of mushroom harvest technique on subsequent American matsutake production. For Ecol Manag 236:65-75

MacDougall AS, Turkington R (2005) Are invasive species the drivers or passengers of change in degraded ecosystems? Ecology 86:42-55

Marx DH (1991) The practical significance of ectomycorrhizae in forest establishment. In: Ecophysiology of ectomycorrhizae of forest trees, Marcus Wallenberg Foundation Symposia Proceedings: 7, Marcus Wallenberg Foundation, Falun, Sweden, pp 54-90

Melent'ev AI, Helisto P, Kuz'mina LY, Galimzyanova NF, Aktuganov GE, Korpela T (2006) Use of antagonistic bacilli for biocontrol of fungi degrading fresh wood. Appl Biochem Microbiol 42:62-66

Milgroom MG, Cortesi P (2004) Biological control of chestnut blight with hypovirulence: a critical analysis. Annu Rev Phytopathol 42:311-338

Moeller HV, Dickie IA, Peltzer D, Fukami T (2015) Mycorrhizal co-invasion and novel interactions depend on neighborhood context. Ecology 96:2336-2347

Motiejunaite J, Kasparavicius J, Kacergius A (2011) Boletellus projectellus - an alien mycorrhizal bolete new to Europe. Sydowia 63:203-213

Murat C, Zampieri E, Vizzini A, Bonfante P (2008) Is the Perigord black truffle threatened by an invasive species? We dreaded it and it has happened! New Phytol 178:699-792

Nuñez MA, Dickie IA (2014) Invasive belowground mutualists of woody plants. Biol Invasions 16:645-661

Nuñez MA, Horton TR, Simberloff D (2009) Lack of belowground mutualisms hinders Pinaceae invasions. Ecology 90:2352-2359

Nuñez MA, Kuebbing S, Dimarco RD, Simberloff D (2012) Invasive species: to eat or not to eat, that is the question. Conserv Lett 5:334-341

Nuñez MA, Hayward J, Horton TR, Amico GC, Dimarco RD, Barrios-Garcia MN, Simberloff D (2013) Exotic mammals disperse exotic fungi that promote invasion by exotic trees. PLOS ONE 8:e66832

Nuñez MA, Dimarco RD, Dickie IA, Pauchard A (2015) ¿Qué puede salir mal?: Los riesgos de introducir microorganismos del suelo de la Antártida en América del Sur. Bosque (Valdivia) 36:343-346

Orlovich DA, Cairney JWG (2004) Ectomycorrhizal fungi in New Zealand: current perspectives and future directions. N Z J Bot 42:721-738

Page F, Westcott B (2014) High numbers of death cap mushrooms around Canberra. April 29, 2014. Canberra Times. http://www.canberratimes.com.au/act-news/high-numbers- of-death-cap-mushrooms-around-canberra-20140429-37 fiv.html. Last accessed 3 April 2016

Pilz D, Molina R (2002) Commercial harvests of edible mushrooms from the forests of the Pacific Northwest United States: issues, management, and monitoring for sustainability. For Ecol Manag 155:3-16

Pringle A, Vellinga EC (2006) Last chance to know? Using literature to explore the biogeography of and invasion biology of the death cap mushroom Amanita phalloides (Vaill. Ex Fr.:Fr) Link. Biol Invasions 8:1131-1144

Pringle A, Adams RI, Cross HB, Bruns TD (2009a) The ectomycorrhizal fungus Amanita phalloides was introduced and is expanding its range on the West Coast of North America. Mol Ecol 18:817-833

Pringle A, Bever JD, Gardes M, Parrent JL, Rillig MC, Klironomos JN (2009b) Mycorrhizal symbioses and plant invasions. Annu Rev Ecol Evol Syst 40:699-715

Rejmánek M, Pitcairn MJ (2002) When is eradication of exotic pest plants a realistic goal. In: Veitch CR, Clout MN (eds) Turning the tide: the eradication of invasive species. Proceedings of the international conference on eradication of island invasives. Occasional paper of the IUCN species survival commission no. 27, pp 249-253

Rivera Y, Kretzer AM, Horton TR (2015) New microsatellite markers for the ectomycorrhizal fungus Pisolithus tinctorius sensu stricto reveal the genetic structure of US and Puerto Rican populations. Fungal Ecol 13:1-9

Schwartz MW, Hoeksema JD, Gehring CA, Johnson NC, Klironomos JN, Abbott LK, Pringle A (2006) The promise and the potential consequences of the global transport of mycorrhizal fungal inoculum. Ecol Lett 9:501-515

Teste FP, Karst J, Jones MD, Simard SW, Durall DM (2006) Methods to control ectomycorrhizal colonization: effectiveness of chemical and physical barriers. Mycorrhiza 17:51-65

Thiet RK, Boerner REJ (2007) Spatial patterns of ectomycorrhizal fungal inoculum in arbuscular mycorrhizal barrens communities: implications for controlling invasion by $\mathrm{Pi}$ nus virginiana. Mycorrhiza 17:507-517

Trappe JM, Molina R, Castellano M (1984) Reactions of mycorrhizal fungi and mycorrhiza formation to pesticides. Annu Rev Ecol Syst 22:331-359

Vellinga EC, Kuyper TW (2012) Exotic etomycorrhizal fungi. Coolia 55:55-64

Vellinga EC, Wolfe BE, Pringle A (2009) Global patterns of ectomycorrhizal introductions. New Phytol 181:960-973

Walbert K, Ramsfield TD, Ridgway HJ, Jones EE (2010) Ectomycorrhizal species associated with Pinus radiata in New Zealand including novel associations determined by molecular analysis. Mycorrhiza 20(3):209-215

Wolfe BE, Richard F, Cross HB, Pringle A (2010) Distribution and abundance of the introduced ectomycorrhizal fungus Amanita phalloides in North America. New Phytol 185:803-816

Wood JR, Dickie IA, Moeller HV, Peltzer DA, Bonner KI, Rattray G, Wilmshurst JM (2015) Novel interactions between non-native mammals and fungi facilitate establishment of invasive pines. J Ecol 103:121-129 